\title{
Installation of Infiltration Gallery at Greens Creek Mine - Juneau, Alaska
}

\author{
Thomas M. Hanna ${ }^{1, *}$, Eric Sundberg ${ }^{2}$, Gabriel Hayden ${ }^{2}$ \\ ${ }^{1}$ Johnson Screens, Durango, Colorado, USA \\ ${ }^{2}$ Greens Creek Mine, Juneau, Alaska, USA
}

Copyright $\bigcirc 2016$ by authors, all rights reserved. Authors agree that this article remains permanently open access under the terms of the Creative Commons Attribution License 4.0 International License

\begin{abstract}
The Greens Creek Mine is located on Admiralty Island, near Juneau Alaska. It is one of the nation's largest silver producers, with a projected 10-year mine life. Bedrock in the vicinity of the mine consists of relatively impermeable argillites. The only reliable water source for the mine and milling operations is the alluvium along the narrow stream bed of Greens Creek. The original source water for the mine consisted of three wells competed in the shallow alluvium of Greens Creek. However, the wells were too shallow and became ineffective in providing an adequate water supply due to freezing in the winter causing aufeis conditions and sediment production at times when the creek was experiencing high run off. In 2009 the wells were replaced with an infiltration gallery completed in the stream bed that would not be affected by the bedload movement and freezing that would damage the intakes and reduce capacity in the winter months. Estimates of the production from a bed mounted infiltration gallery were used to determine screen length and configuration in the streambed to provide a minimum of $3,800 \mathrm{~m}^{3} /$ day water supply needed by the mine. A Johnson Screens, Muni-pak screen was selected as the intake to address problems that might occur with excessive stream bed erosion that occurs during large storm events and provide filtration during periods of high flow and turbidity. The main challenge during the construction phase was to maintain the 3,800 $\mathrm{m}^{3} /$ day flow to the mine and mill operations while decommissioning the old well system and installing the new infiltration gallery. During construction, Greens Creek was diverted and the infiltration gallery was excavated, installed in the streambed and connected to the existing stilling well. The new system has been operational for about 2 years without problems at a capacity of $3800 \mathrm{~m}^{3} /$ day with minimal drawdown in the stilling well.
\end{abstract}

Keywords Aufeis, Alaska, Alluvium, Hydraulic Conductivity, Infiltration Gallery, Muni-pak, Streambed, Water Supply

\section{Introduction}

The Greens Creek Mine requires a 3,800 m3/day water supply for running the mine and milling operations. The original water supply system which was installed in 1988 consisted of three shallow wells that were placed in the alluvium of Greens Creek. The wells became ineffective in providing an adequate water supply due to freezing in the winter and sediment production at times when the creek was experiencing high run off.

A new infiltration gallery was designed and installed to restore the capacity of the well system to a reliable water source with a minimum capacity of $3,800 \mathrm{~m}^{3} /$ day. The infiltration gallery was constructed using Johnson Screens Muni-Pak screens placed horizontally along the bottom of the creek bed alluvium in a bed of pre-filter gravel. This configuration allows the active bed load to pass over the top of the screens without exposing the screens to the creek and be placed at a depth below the aufeis (frozen stream bed) to prevent winter freezing allowing maximum capacity in changing conditions.

\section{Mine Location and Background}

Located on Admiralty Island, near Juneau Alaska (Figure 1), the Greens Creek Mine is owned and operated by the Hecla Mining Company with over 330 employees. The Greens Creek silver, gold, zinc and lead underground mine and concentrator facility began operation in 1989, but was placed on standby in 1993, A US\$114 million modernization and redevelopment investment over a three-year period was completed and operations resumed in 1996 and are continuing to this day.

With a projected 10-year mine life, Greens Creek is one of the nation's largest silver producers in North America. The operation originally had a designed mining and processing rate of $1.2 \times 10^{6} \mathrm{~kg}$ per day; the rate in 2010 had nearly doubled to $2.1 \times 10^{6} \mathrm{~kg}$ per day. 


\section{Original Well System}

The original well system was installed in 1988 to provide $3,800 \mathrm{~m}^{3} /$ day of fresh, non-turbid water to the mine and milling operation and is a critical operational requirement. As the well system aged, lower flow rates and sediment production were experienced, resulting in water management difficulties that altered metallurgical strategies in the milling operation and mine economics. The necessary supply of $3,800 \mathrm{~m}^{3} /$ day was often reached in the summer, but during periods of high-flow the water in the creek became turbid and without proper filtration around the wells high turbidity water was being pumped particularly in the spring and fall. During turbid periods, the well screens were required to be backwashed with air as frequently as every two hours to maintain flow, further reducing the capacity of the water-supply system. In addition, during the winter months the wells would freeze due to aufeis conditions to a depth of $0.6 \mathrm{~m}$, closing the slots on the screens, which would drop the water supply below the minimum requirements to run the mining and milling operations.

The three old wells were constructed of $1,219 \mathrm{~mm}$ (48-in), $2.5 \mathrm{~mm}(0.100$-in) slot, 304 stainless steel, wire wrap Johnson Screens. The wells were completed by excavating the streambed and placing them so that to top of the screens were just below the streambed. Each well had $1.4 \mathrm{~m}$ of screen in a vertical orientation and was completed with a 51 $\mathrm{mm}$ (2-in) backwash line that was used to pump high pressure air using nozzles that were oriented through the screen into the gravels to remove clogging.

The original wells were spaced at approximately $4.6 \mathrm{~m}$ intervals along the center of the stream. Steel baskets were placed around the wells and filled with gravels and cobbles for stability and filtration. The baskets were only capable of holding coarse gravel and coble sized materials that were not adequate for filtration of sands. The wire baskets were damaged during high flow events by the shifting bed loads and were not effective in maintaining the filter materials around the wells resulting in the pumping of sediment. Additionally it was discovered upon decommissioning, the wells were completed without plate bottoms. This serious design flaw allowed gravel and sand entrance into the water supply after the baskets had failed.

The old wells were connected through a series of three, $305 \mathrm{~mm}$ (12-in) pipes to a $2.4 \mathrm{~m}$ diameter stilling well that housed 3 pumps. Each pump has a capacity in excess of $3,800 \mathrm{~m}^{3} /$ day to allow any one pump to meet peak demand and provide backup capacity. Low, water-level cutoff switches were used to reduce pumping when that water level in the stilling well dropped below the $305 \mathrm{~mm}$ (12-in) inlet pipes from the wells.

\section{Site Hydrogeology}

The general geology of the site is Quaternary alluvial, creek bed deposits of cobles, gravel, and sand that are overlying landslide materials and relatively impermeable glacial tills and argillite (Twelker, 2009) that act as an impermeable basement and all of the usable ground water is in the shallow streambed alluvial system. The upper $4.6 \mathrm{~m}$ of streambed alluvium are comprised of well sorted cobles, gravels and sands that are part of the active bed load. The sands and gravels have a thickness of less than $30 \mathrm{~m}$. Water from the deeper portions (approximately deeper than $5 \mathrm{~m}$ ) of the alluvium is highly mineralized and not of quality suitable for potable water or mine processing negating the use of deeper wells. Flows in Greens Creek range from highs of $613,000 \mathrm{~m}^{3} /$ day during the spring runoff to lows of 12,000 $\mathrm{m}^{3} /$ day in the winter months; however, the flow of water in the sands and gravels of the creek is significant.

Greens Creek has an active bed load and it is common for the upper $0.6-1.2 \mathrm{~m}$ of the bed to move during times of high runoff. The stream alluvium at the well site is approximately $10 \mathrm{~m}$ wide. Figure 3 presents a generalized cross section of Greens Creek at the location of the well.

\section{Site Investigation and Infiltration Gallery Design}

The initial site investigation involved a review of the pumping history of the existing well system, site hydrogeology and records concerning the performance of the existing three-well system. The most important aspects of a new design would be to provide a water-supply system that must eliminate pumping of sediment and be installed below the aufeis to prevent freezing along with providing a minimum of $3,800 \mathrm{~m}^{3} /$ day during any time of the year. The new well design must also be compatible with the existing stilling well and $305 \mathrm{~mm}$ (12-in) transmission pipes. To meet these requirements it was determined that a horizontal screen intake configured as an infiltration gallery would be a more efficient way of designing the system and preventing aufeis from damaging the intakes and reducing capacity in the winter months, while still pumping water of acceptable quality for the mine.

The primary area targeted for the location of the infiltration gallery was in a small narrows in the creek where the river gradient is the steepest and the stream bed would have gravels with the greatest hydraulic conductivity (Figure 4).

A Johnson Screens, Muni-pak screen was selected as the intake to prevent any problems that might occur with excessive stream bed erosion that are common in heavy stream runoff events and provide filtration under high flow conditions. With the Muni-pak screen, even if there was extreme erosion and the screens were exposed to the streambed the integrated filter pack would prevent significant amounts of fine sand and any coarse sand and gravel from entering the intake which had been a problem with the former design. The high runoff events were responsible for damage to the existing system when the 
screens were eroded and cobles impacted the screens causing damage that resulted in excessive pumping of gravel and coble sized materials.

Estimates of the production from a bed-mounted infiltration gallery were used (Sterrett, 2007) to estimate the screen length. The equation used for estimating the length of the infiltration gallery is:

$$
L=\frac{0.366 Q \log (1.1 d / r)}{0.25 K H}
$$

Where:

$\mathrm{L}=$ length of infiltration screen $(\mathrm{m})$.

$\mathrm{K}=$ hydraulic conductivity of gravel bed ( $\mathrm{m} /$ day).

$\mathrm{H}=$ submergence of infiltration screen (distance from stream surface to centre of screen $(\mathrm{m})$.

$\mathrm{Q}=$ inflow rate in $\left(\mathrm{m}^{3} /\right.$ day $)$.

$\mathrm{d}=$ distance from streambed to centre of screen $(\mathrm{m})$.

$\mathrm{r}=$ radius of well $(\mathrm{m})$.

Using a hydraulic conductivity of $\mathrm{K}=400 \mathrm{~m} /$ day (clean gravel), submergence $\mathrm{H}=2 \mathrm{~m}$, distance to streambed $\mathrm{d}=1.2$ $\mathrm{m}$ and radius of well screen $\mathrm{r}=0.25 \mathrm{~m}$ and a anticipated pumping rate of $3,800 \mathrm{~m}^{3} /$ day results in an estimated length for the intake for the infiltration gallery of approximately 5 $\mathrm{m}$.

To ensure infiltration capacity the infiltration gallery was designed with a backfill over an area greater than $46 \mathrm{~m}^{2}$ of coarse gravel material around the infiltration gallery (Sterrett, 2007) to enhance infiltration.

The intake screens were designed by first ensuring that the axial velocity of the intake was less than $0.9 \mathrm{~m} / \mathrm{sec}(3 \mathrm{ft} / \mathrm{sec})$ and screen entrance velocity less than $0.03 \mathrm{~m} / \mathrm{sec}(0.1 \mathrm{ft} / \mathrm{sec})$ while allowing for blockage of the screen that might occur if the screens are exposed in the creek bottom and silted in after a large storm event. Based on these criteria $9.1 \mathrm{~m}$ of $559 \mathrm{x}$ $508 \mathrm{~mm}$ ( 22 x 20-in) Muni-Pak screen with a $2.5 \mathrm{~mm}$ (0.1-in) slot and filter pack of 3.3- to 2.9-mm diameter glass SiLi beads was selected as the intake. Glass SiLi beads were selected because they are more hydraulically efficient than natural gravels and are more resistant to biofouling that can clog well screens. The $559-508 \mathrm{~mm}$ Muni-pak screens have an inflow capacity of over $10,000 \mathrm{~m} /$ day at less than 0.03 $\mathrm{m} / \mathrm{sec}$ inflow velocity through the inner screen, providing sufficient capacity for any mine expansion.

The screens were equipped with a $51 \mathrm{~mm}$ (2-in) air burst pipe that is used to redevelop and clean the screen in the event they become clogged. The airburst pipe is centered in the middle of the screens and is perforated across the entire length opposite the screen openings (Figure 5).

\section{Completion of Infiltration Gallery}

The existing wells were decommissioned and the infiltration gallery was completed from February 12 through $18,2009$.

The main challenge of the construction phase was to maintain the $3,800 \mathrm{~m}^{3} /$ day flow to the mine and mill operations while decommissioning the existing screens and installing the new screens. Any interruption of the fresh water would result in the milling operations coming to a stop, potentially causing significant revenue loss.

The solution to this challenge was to install a temporary impoundment structure upstream of the well site, and route the creek flow around the well site through 610 and $914 \mathrm{~mm}$ (24- and 36-in) culverts. Flygt pumps were placed upstream of the impoundment, and water was pumped directly into the stilling well for distribution to the mine. Valves that connected the wells to the stilling well were closed, effectively isolating the construction site from the water-supply system providing uninterrupted fresh water to the mine and mill.

The impoundment structure was manufactured by Aquabarrier, and was capable of impounding a maximum of $2 \mathrm{~m}$ of water behind the barrier. Because typical creek flows would quickly overwhelm the barrier, the construction project had to take place during a cold winter period, when the creek flow was $36,700 \mathrm{~m}^{3} /$ day or less and at a time that salmon are not spawning, which precludes work in the summer months. A previous attempt to install the barrier early the previous spring was unsuccessful because of temperatures were above freezing resulting in higher than anticipated stream flow, that could not be managed by the barrier.

Once the barrier was in place, a deep sump was dug in the stream bed downstream of the barrier, and upstream of the well site. The purpose of this sump was to intercept groundwater flow into the excavation. A portable Godwin pump capable of pumping $25,000 \mathrm{~m}^{3} /$ day was used to dewater the sump. The high hydraulic conductivity of the stream bed was demonstrated in this operation, as the pump could barely keep up with the dewatering demand.

The area of the infiltration gallery was excavated to a depth of approximately $2 \mathrm{~m}$ below the stream bed, the 1,219 $\mathrm{mm}$ (48-in) screens were removed and the discharge piping was inspected and repaired as needed to accommodate the new infiltration gallery. The new Muni-Pak screens were attached to the existing $305 \mathrm{~mm}$ (12-in) lines as shown in Figure 6. One screen was placed across the stream and the second was placed perpendicular to the direction of flow to maximize the geometry of the available space and make connections to the existing piping. 


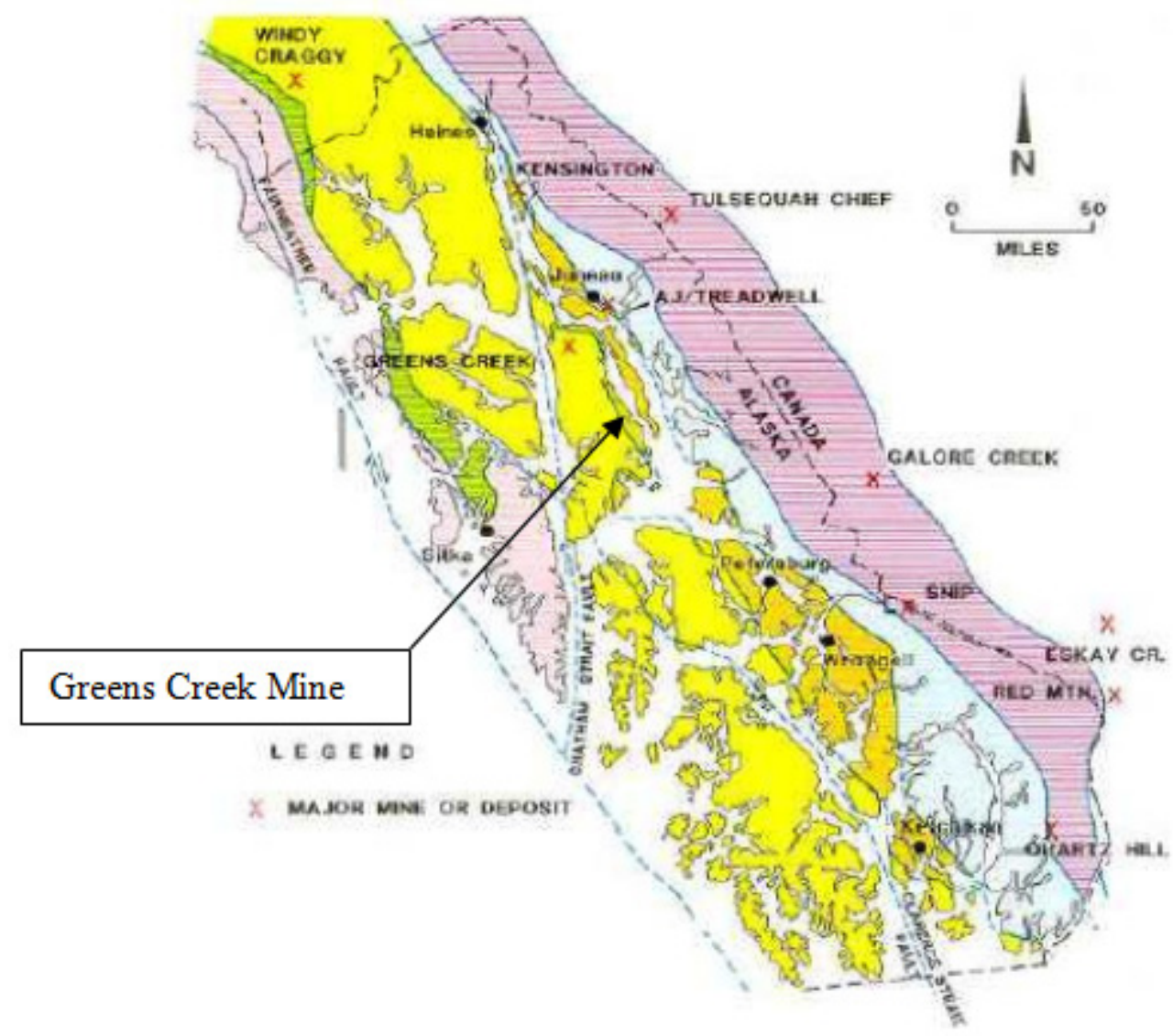

Figure 1. Location of the Greens Creek Mine, SE Alaska

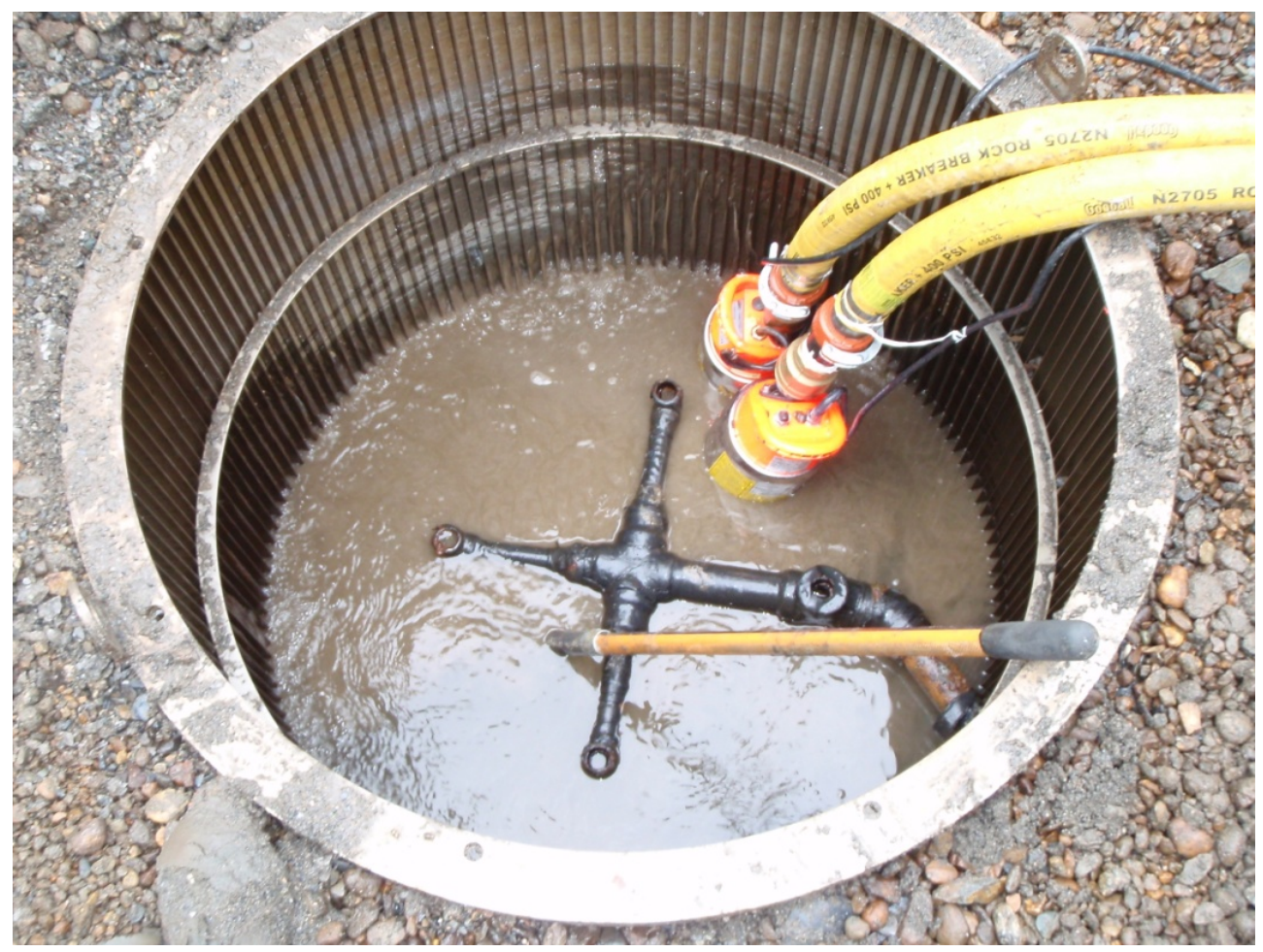

Figure 2. $1219 \mathrm{~mm}$ (48-in) well with jetting nozzles 


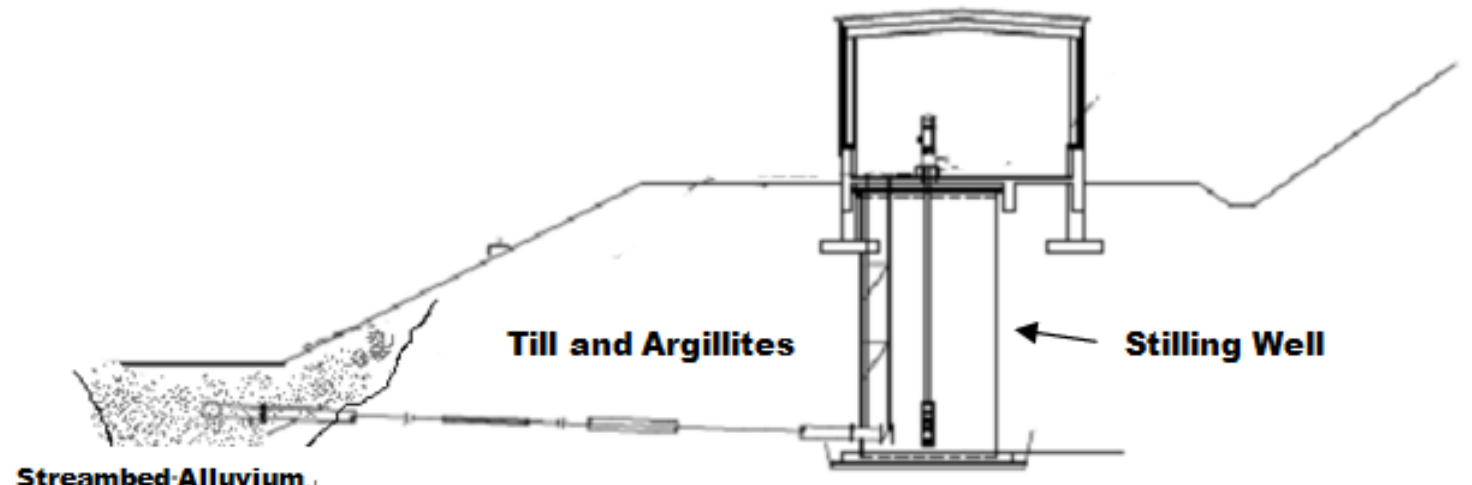

Streambed Alluvium

Figure 3. Generalized cross section of Greens Creek infiltration gallery

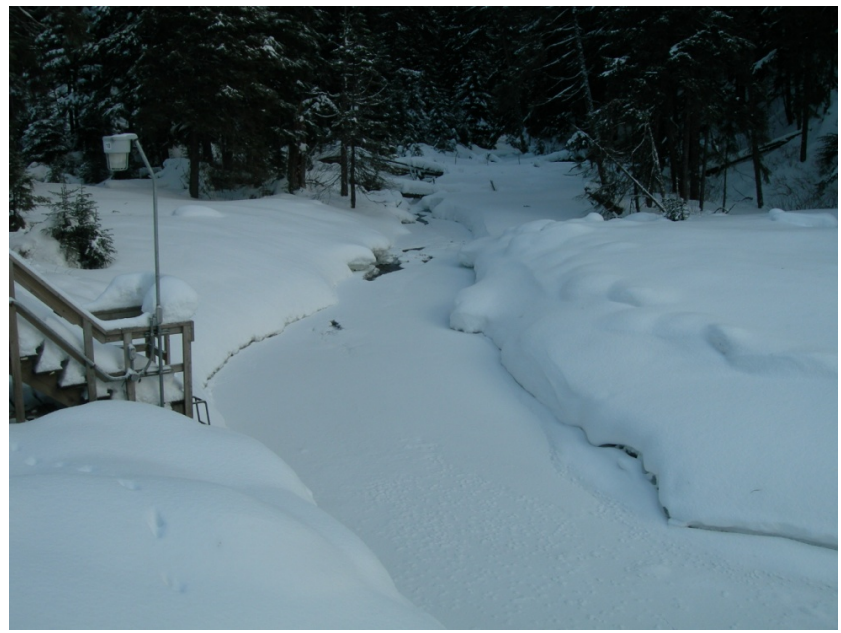

Figure 4. Creek at the site of the infiltration gallery prior to installation

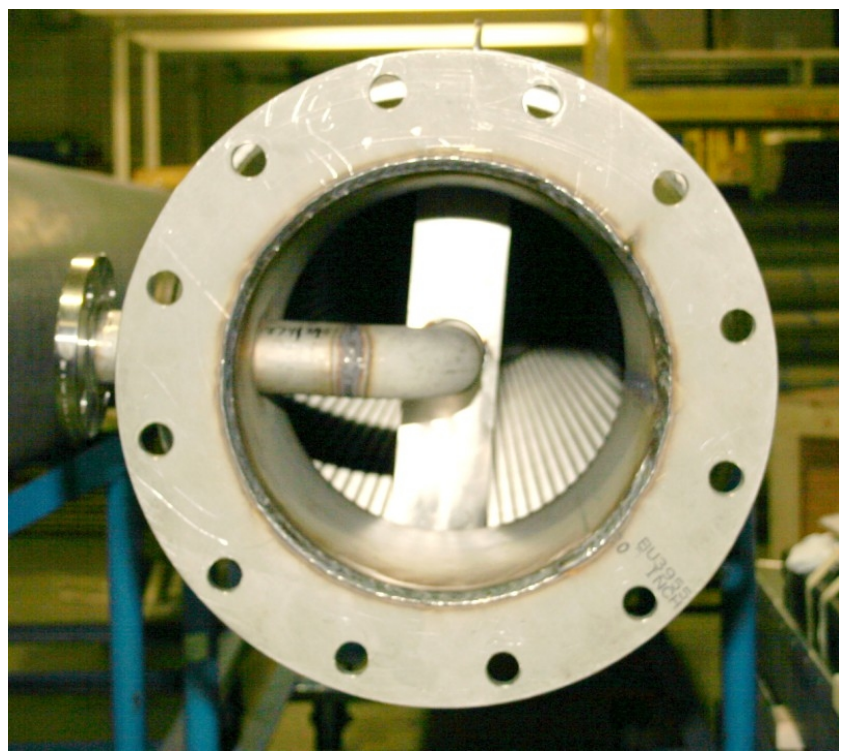

Figure 5. Muni-pak screen with airburst system

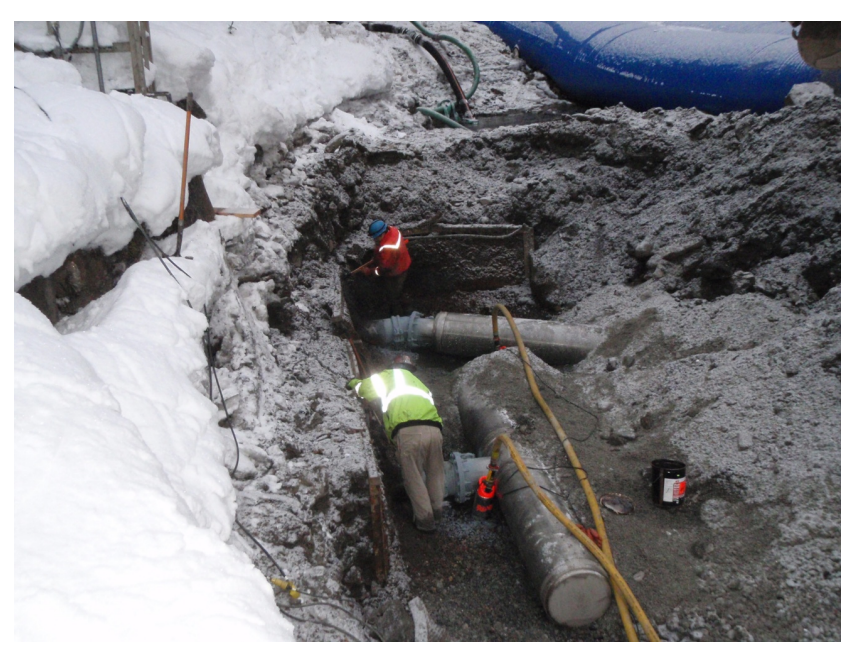

Figure 6. Infiltration gallery prior to covering with $916 \mathrm{~mm}$, minus rock and coarse rock $25-50 \mathrm{~mm}$

The screens were backfilled with $9.53 \mathrm{~mm}$, plus clear-crush imported rock. Approximately $0.6 \mathrm{~m}$ of backfill material was placed over and around the screens. Coarse, 25 - $50 \mathrm{~mm}$ imported rock was used above the $9.53 \mathrm{~mm}$ fill up to the original creek bed level.

After the infiltration gallery construction was completed the barrier was removed and flow was returned to the creek. The screens were then purged with air several times to clean the backfill materials and provide well development.

The wet well was cleaned out using the Vac-Truck. Approximately $7.6 \mathrm{~m}^{3}$ of silt and sand was removed from the wet well. When the job was completed, the steel floor of the wet well was completely free of sediment.

The new infiltration gallery has been operating without any operational issues for 16 months. Back flushing is now required only during larger runoff events and there have not been any water supply problems for the mining operations. The pumping system has pumped above the $3,800 \mathrm{~m}^{3} /$ day minimum requirement without the system shutting down due to low water level. This is a vast improvement over the original system, indicating that the infiltration gallery is operating more efficiently. 


\section{Conclusions}

Replacement of the three, 1,219 mm (48-in) wells was accomplished with an infiltration gallery consisting of $9.1 \mathrm{~m}$ $(30 \mathrm{ft})$ of Muni-Pak screen. Orientation of the infiltration gallery allows sediment free operation of the water-supply system during large runoff events that in the past had been problematic with production of fines. After sixteen months of operation the infiltration gallery is operating sediment free and the stilling well is clean of sands and gravels without have to use the airburst system to clean the wells. Production has more than exceeded to mine requirements.

\section{REFERENCES}

[1] Sterrett R.J. (2007) Groundwater and Wells 3rd Edition, Johnson Screens, New Brighton, MN, 812 p.

[2] Twelker, Eric (2009) Greens Creek Geology, 23 p., viewed march 2011, http://www.erictwelker.com/greenscreek.htm 